\title{
Determination of Heavy Metals and Polycyclic Aromatic Hydrocarbons (PAH) Contents Using the Lichen Dirinaria picta in Universiti Kebangsaan Malaysia
}

\author{
Mohd Wahid Samdudin ${ }^{1 *}$, Husna Azahar ${ }^{1}$, Azlan Abas ${ }^{2}$, Zuriati Zakaria ${ }^{3}$ \\ ${ }^{1}$ Department of Chemical Science \& Food Technology, Faculty of Science \& Technology, National University of Malaysia, Bangi, \\ Malaysia; ${ }^{2}$ Faculty of Social Science \& Humanities, National University of Malaysia, Bangi, Malaysia; ${ }^{3}$ Malaysia Japan International \\ Institute of Technology, Technology University of Malaysia, Kuala Lumpur, Malaysia. \\ Email: *mohdwahid.samsudin@yahoo.com
}

Received June $17^{\text {th }}, 2013$; revised July $18^{\text {th }}, 2013$; accepted July $25^{\text {th }}, 2013$

Copyright (c) 2013 Mohd Wahid Samdudin et al. This is an open access article distributed under the Creative Commons Attribution License, which permits unrestricted use, distribution, and reproduction in any medium, provided the original work is properly cited.

\begin{abstract}
A biomonitoring study on lichens was conducted to assess the levels of atmospheric heavy metal and polycyclic aromatic hydrocarbon (PAH) at ten sites at the Universiti Kebangsaan Malaysia Campus, Bangi, Selangor, Malaysia. Dirinaria picta, epiphytic lichen which commonly found at lowland areas was used as the bioindicator in this study where samples were collected from the bark of palm trees at sites ranging from areas with high volume of traffic to isolated areas in the campus. Eight metals $(\mathrm{Cr}, \mathrm{Fe}, \mathrm{Co}, \mathrm{Ni}, \mathrm{Cu}, \mathrm{Zn}, \mathrm{Al}, \mathrm{Pb})$, and ten $\mathrm{PAH}$; naphthalene $\left(\mathrm{PAH}_{1}\right)$, acenaphtylene $\left(\mathrm{PAH}_{2}\right)$, acenaphthene $\left(\mathrm{PAH}_{3}\right)$, fluorine $\left(\mathrm{PAH}_{4}\right)$, anthracene $\left(\mathrm{PAH}_{5}\right)$, phenanthrene $\left(\mathrm{PAH}_{6}\right)$, fluoranthene $\left(\mathrm{PAH}_{7}\right)$, pyrene $\left(\mathrm{PAH}_{8}\right)$, benzo (b) anthracene $\left(\mathrm{PAH}_{9}\right)$ and chrysene $\left(\mathrm{PAH}_{10}\right)$ were analyzed in the naturally growing thallus of Dirinaria picta. The average concentration of the metals was observed to be in the range of $230.6 \mathrm{ppm}(\mathrm{Fe})$ to $0.3 \mathrm{ppm}$ (Co) and for $\mathrm{PAH}$, it was observed in the range of $612 \mathrm{ppm}\left(\mathrm{PAH}_{1}\right)$ to $79.5 \mathrm{ppm}\left(\mathrm{PAH}_{10}\right)$. The One-way ANOVA analysis for both the heavy metals and the PAHs showed $\mathrm{H}_{0}$ was rejected. There are significant differences in heavy metals and PAHs concentrations between sites. The selectivity sequence of heavy metals were $\mathrm{Fe}>\mathrm{Cr}>\mathrm{Ni}>\mathrm{Al}>\mathrm{Zn}>$ $\mathrm{Pb}>\mathrm{Cu}$. Meanwhile for $\mathrm{PAH}$, the sequence is $\mathrm{PAH}_{1}>\mathrm{PAH}_{3}>\mathrm{PAH}_{2}>\mathrm{PAH}_{6}>\mathrm{PAH}_{5}>\mathrm{PAH}_{7}>\mathrm{PAH}_{4}>\mathrm{PAH}_{8}>\mathrm{PAH}_{9}$ $>\mathrm{PAH}_{10}$.
\end{abstract}

Keywords: Air Quality; Bioindicator; Heavy Metals; PAH; Dirinaria picta

\section{Introduction}

The developmental efforts in Malaysia to become an industrialized nation by 2020 has had a significant effect on the quality of air that in turn negatively affects public health and her diverse ecosystem. The three major causes of air pollution are transportation, stationary sources and open burning [1]. The Department of Environment is the body that carries out air pollution control and monitoring as a means to offset the decreasing air quality in the nation $[2,3]$. The problem they face now is that the quality of air in areas far away from their air monitoring stations is difficult to determine, hence lichen has been selected as a potential bioindicator for this purpose.

Lichen is a very unique species which exists in a symbiotic relationship between fungus and algae. This species has no complex organs such as roots, leaves or bark

*Corresponding author.
[4]. The use of lichen as a potential bioindicator to measure the air quality has long been recognized since last few decades [5]. Their anatomy and morphology which has no waxy cuticle on the upper surface has made the accumulation of air particles with heavy metal and polycyclic aromatic hydrocarbon (PAHs) contents feasible.

Heavy metals and PAHs are common parameters that could be measured to determine the level of air quality. Heavy metals such as cadmium, lead and mercury are common air pollutants emitted as a result of various industrial activities and have been reported to have adverse effects on human health [6]. PAHs are semi-volatile organic compounds, distributed both in the vapor- and particle-phases of the air. The sources of these compounds are mainly from industrial activities and vehicles emissions [6]. Many researchers are interested to study about PAHs in atmosphere because of their mutagenic and car- 
cinogenic characteristic [7]. The simplest technique to determine both heavy metals and PAHs content is ICPOES and gas chromatography respectively.

\section{Experimental Design}

\subsection{Sampling}

The samples of lichen Dirinaria picta were collected around UKM, Bangi at ten locations (Figure 1). Sites 1-6 are near the entrance of the University where traffic is busy along the public road, whilst sites $7,8 \mathrm{a}$ and $8 \mathrm{~b}$ are at the inner campus where the traffic are limited to vehicles used by UKM staff and students. Sites 9a, 9b and 10 are located at a quieter place where very few vehicles pass by. The lichens were cleaned, oven dried at $60^{\circ} \mathrm{C}$ for 48 hours and ground for further analysis.

\subsection{Heavy Metal Analysis}

The ground samples then were homogenized. About $1 \mathrm{~g}$ of samples was weighted accurately for 3 replicates and digested using wet acid digestion procedure [8-10]. The acid mixture used for digestion is $5.0 \mathrm{~mL}$ nitric acid $65 \%$ and $2.0 \mathrm{~mL}$ hydrogen peroxide $30 \%$. After that, the mixtures were heated on the hot plate at $90^{\circ} \mathrm{C}$ for 4 hours. The residue of digestion then was rinsed by with $1 \mathrm{~mL}$ hydrochloric acid $2 \%$ and diluted to 100 by deionized water before carrying out the ICP-OES (Optima 4300 DV, Perkin Elmer) analysis.

\subsection{Polycyclic Aromatic Hydrocarbon Analysis}

Approximately, $2 \mathrm{~g}$ of ground sample was extracted in a Soxhlet apparatus with $250 \mathrm{~mL}$ dichloromethane (DCM) for $24 \mathrm{~h}$ gel column with $25 \mathrm{~mL}$ of DCM: pentane (2:3 $\mathrm{v} / \mathrm{v})$ as eluting solvent. The samples were again evaporated and concentrated with a gentle stream of purified nitrogen to $1 \mathrm{~mL}$. Then, they were analyzed using Gas Chromatography/Mass Spectrometer (GC/MS) (Agilent 7890A coupled with Agilent 5975C MS system) by using

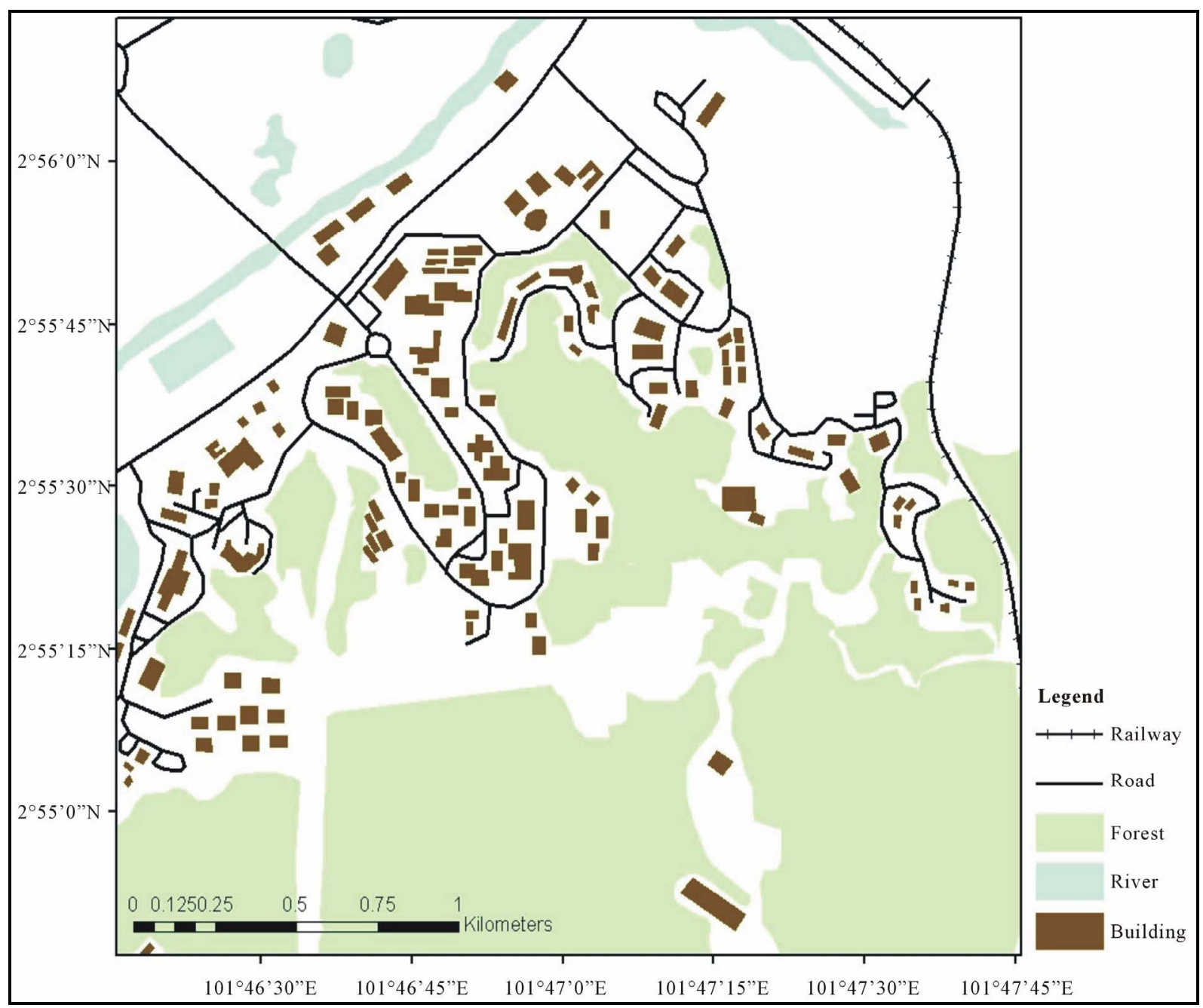

Figure 1. Sampling locations, Universiti Kebangsaan Malaysia, Bangi, Selangor, Malaysia. 
AB-5MS capillary column. The identification of PAH compounds were carried out by both mass spectra and retention time compared to external PAH standard.

\subsection{Statistical Analysis}

One-way ANOVA is tested to evaluate the result of heavy metals and PAHs concentration. SNK Test was also performed to check significant comparisons between each of the heavy metals and PAHs.

\section{Result and Discussion}

In this study, the heavy metals found are $\mathrm{Fe}, \mathrm{Cr}, \mathrm{Ni}, \mathrm{Zn}$, $\mathrm{Al}, \mathrm{Pb}$ and $\mathrm{Co}$. Meanwhile, the PAHs found are napthalene $\left(\mathrm{PAH}_{1}\right)$, acenaphtylene $\left(\mathrm{PAH}_{2}\right)$, acenaphthene $\left(\mathrm{PAH}_{3}\right)$, fluorine $\left(\mathrm{PAH}_{4}\right)$, anthracene $\left(\mathrm{PAH}_{5}\right)$, phenanthrene $\left(\mathrm{PAH}_{6}\right)$, fluoranthene $\left(\mathrm{PAH}_{7}\right)$, pyrene $\left(\mathrm{PAH}_{8}\right)$, benzo (b) anthracene $\left(\mathrm{PAH}_{9}\right)$ and chrysene $\left(\mathrm{PAH}_{10}\right)$.

Tables 1 and 2 show the analysis of heavy metals and
PAHs concentration. Based on Table 1, the average concentration of heavy metals was in the range between $0.316 \mathrm{ppm}(\mathrm{Co})$ and $230.55 \mathrm{ppm}(\mathrm{Fe})$. Almost all concentration of heavy metals at location 2 gave the highest reading except for metal $\mathrm{Cu}(\mathrm{Fe}=485.20 \pm 3.21 \mathrm{ppm}, \mathrm{Cr}$ $=107.8 \pm 3.75 \mathrm{ppm}, \mathrm{Ni}=53.79 \pm 2.34 \mathrm{ppm}, \mathrm{Zn}=14.35$ $\pm 2.76 \mathrm{ppm}, \mathrm{Al}=29.38 \pm 3.42 \mathrm{ppm}, \mathrm{Pb}=2.758 \pm 0.54$ ppm and $\mathrm{Co}=0.71 \pm 0.23 \mathrm{ppm}$ ). For metal $\mathrm{Cu}$, the highest reading was recorded at Location $3(2.68 \pm 1.05 \mathrm{ppm})$. Meanwhile, for PAHs analysis (Table 2), the average concentration was in the range between $27.62 \mathrm{ppm}$ $\left(\mathrm{PAH}_{10}\right)$ and $177.13 \mathrm{ppm}\left(\mathrm{PAH}_{1}\right)$. Location 1 gave the highest concentration for almost of the PAHs except for $\mathrm{PAH}_{6}$ and $\mathrm{PAH}_{9}$. For $\mathrm{PAH}_{6}$ and $\mathrm{PAH}_{9}$, the highest reading was recorded at Location 3 . The highest concentration reading for $\mathrm{PAHs}$ are; $\mathrm{PAH}_{1}(612.80 \mathrm{ppm}), \mathrm{PAH}_{2}$ (369.20 ppm), $\mathrm{PAH}_{3}$ (395.30 ppm), $\mathrm{PAH}_{4}(283.80 \mathrm{ppm})$, $\mathrm{PAH}_{5}$ (189.90 ppm), $\mathrm{PAH}_{6}$ (178.80 ppm), $\mathrm{PAH}_{7}(290.30$ ppm), $\mathrm{PAH}_{8}(168.10 \mathrm{ppm}), \mathrm{PAH}_{9}(120.90 \mathrm{ppm})$ and

Table 1. Heavy metal accumulation (ppm) in lichen Dirinaria picta at Universiti Kebangsaan Malaysia, Bangi, Selangor.

\begin{tabular}{|c|c|c|c|c|c|c|c|}
\hline \multirow{2}{*}{$\begin{array}{l}\text { Heavy } \\
\text { metals }\end{array}$} & \multicolumn{7}{|c|}{ Location } \\
\hline & 1 & 2 & 3 & 4 & 5 & & \\
\hline $\mathrm{Cr}$ & $17.45 \pm 0.26$ & $107.8 \pm 3.75$ & $5.69 \pm 1.31$ & $62.88 \pm 3.11$ & $103.00 \pm 4.65$ & \multicolumn{2}{|c|}{$7.343 \pm 2.71$} \\
\hline $\mathrm{Fe}$ & $107.00 \pm 3.15$ & $485.2 \pm 3.21$ & $61.54 \pm 2.94$ & $296.9 \pm 4.32$ & $452.2 \pm 10.32$ & \multicolumn{2}{|c|}{$85.95 \pm 4.16$} \\
\hline Co & $0.11 \pm 0.08$ & $0.71 \pm 0.23$ & $0.047 \pm 0.02$ & $0.43 \pm 0.13$ & $0.6957 \pm 0.16$ & \multicolumn{2}{|c|}{$0.0676 \pm 0.013$} \\
\hline $\mathrm{Ni}$ & $7.94 \pm 1.12$ & $53.79 \pm 2.34$ & $2.15 \pm 0.67$ & $31.47 \pm 3.51$ & $52.07 \pm 3.23$ & \multicolumn{2}{|c|}{$3.464 \pm 0.96$} \\
\hline $\mathrm{Cu}$ & $1.43 \pm 0.32$ & $2.21 \pm 0.88$ & $2.68 \pm 1.05$ & $1.72 \pm 0.56$ & $1.967 \pm 0.37$ & \multicolumn{2}{|c|}{$1.262 \pm 0.83$} \\
\hline Zn & $20.75 \pm 2.73$ & $14.35 \pm 2.76$ & $8.92 \pm 1.77$ & $7.36 \pm 1.18$ & $10.8 \pm 1.22$ & \multicolumn{2}{|c|}{$12.25 \pm 1.34$} \\
\hline $\mathrm{Al}$ & $16.07 \pm 1.67$ & $29.38 \pm 3.42$ & $16.65 \pm 3.02$ & $21.70 \pm 3.32$ & $19.41 \pm 2.59$ & \multicolumn{2}{|c|}{$21.93 \pm 2.78$} \\
\hline $\mathrm{Pb}$ & $2.018 \pm 0.64$ & $2.758 \pm 0.54$ & $1.94 \pm 0.61$ & $2.291 \pm 0.51$ & $1.734 \pm 0.46$ & \multicolumn{2}{|c|}{$1.817 \pm 0.35$} \\
\hline Total & 172.77 & 696.2 & 99.62 & 424.75 & 641.88 & \multicolumn{2}{|c|}{134.08} \\
\hline \multicolumn{8}{|c|}{ One-way ANOVA } \\
\hline F & \multicolumn{7}{|l|}{2.16} \\
\hline Heavy & \multicolumn{5}{|c|}{ Location } & \multirow[t]{2}{*}{ Average } & \multirow[t]{2}{*}{$\mathrm{F}$} \\
\hline metals & 7 & $8 a$ & \multicolumn{2}{|c|}{$9 a$} & 10 & & \\
\hline $\mathrm{Cr}$ & $21.91 \pm 2.68$ & $98.47 \pm 4.54$ & \multicolumn{2}{|c|}{$7.315 \pm 1.16$} & $24.18 \pm 2.74$ & 45.60 & 17.28 \\
\hline $\mathrm{Fe}$ & $146.4 \pm 4.11$ & $437.5 \pm 5.89$ & \multicolumn{2}{|c|}{$75.19 \pm 2.44$} & $157.6 \pm 4.76$ & \multicolumn{2}{|l|}{230.55} \\
\hline Co & $0.1752 \pm 0.045$ & $0.6716 \pm 0.28$ & \multicolumn{2}{|c|}{$0.0732 \pm 0.02$} & $0.1819 \pm 0.03$ & \multicolumn{2}{|l|}{0.32} \\
\hline $\mathrm{Ni}$ & $10.84 \pm 1.95$ & $50.87 \pm 3.77$ & 3.6 & 0.54 & $12.09 \pm 1.06$ & 22.83 & \\
\hline $\mathrm{Cu}$ & $1.352 \pm 0.23$ & $1.413 \pm 0.29$ & & 0.05 & $1.713 \pm 0.085$ & 1.68 & \\
\hline $\mathrm{Zn}$ & $10.91 \pm 1.38$ & $12.11 \pm 1.48$ & 10 & 1.09 & $11.09 \pm 1.38$ & 11.88 & \\
\hline $\mathrm{Al}$ & $26.61 \pm 2.27$ & $24.27 \pm 3.74$ & 17. & 2.13 & $23.75 \pm 3.11$ & 21.75 & \\
\hline $\mathrm{Pb}$ & $1.987 \pm 0.19$ & $1.787 \pm 0.32$ & 1.3 & 0.21 & $2.573 \pm 0.96$ & 2.02 & \\
\hline Total & 220.18 & 627.09 & & & 233.18 & & \\
\hline & way ANOVA & & & & & & \\
\hline $\mathrm{F}$ & 2.16 & & & & & & \\
\hline
\end{tabular}


Table 2. PAH accumulation (ppm) in lichen Dirinaria picta at Universiti Kebangsaan Malaysia, Bangi, Selangor.

\begin{tabular}{|c|c|c|c|c|c|c|c|c|c|c|c|c|}
\hline \multirow[t]{2}{*}{ PAHs } & \multicolumn{10}{|c|}{ Location } & \multirow[t]{2}{*}{ Average } & \multirow[t]{2}{*}{$\mathrm{F}$} \\
\hline & 1 & 2 & 3 & 4 & 5 & 6 & 7 & $8 b$ & $9 b$ & 10 & & \\
\hline $\mathrm{PAH}_{1}$ & 612.80 & 142.80 & 269.80 & 127.30 & 177.20 & 154.90 & 142.80 & 124.3 & 19.42 & n.d. & 177.13 & 6.29 \\
\hline $\mathrm{PAH}_{2}$ & 369.20 & 110.20 & 140.80 & 111.10 & 64.20 & 20.45 & 21.99 & 6.98 & 7.26 & n.d. & 85.22 & \\
\hline $\mathrm{PAH}_{3}$ & 395.30 & 189.20 & 139.30 & 44.92 & 61.14 & 20.07 & 11.89 & 7.78 & 5.63 & 6.89 & 88.21 & \\
\hline $\mathrm{PAH}_{4}$ & 283.80 & 45.60 & 135.90 & 48.19 & 45.34 & 24.90 & 4.56 & 4.37 & 4.56 & n.d. & 59.72 & \\
\hline $\mathrm{PAH}_{5}$ & 198.90 & 119.90 & 142.60 & 75.63 & 161.20 & 12.29 & 8.55 & 5.13 & 9.33 & n.d. & 73.35 & \\
\hline $\mathrm{PAH}_{6}$ & 148.80 & 168.80 & 178.80 & 50.39 & 175.20 & 10.72 & 14.84 & 4.63 & 5.23 & n.d. & 75.74 & \\
\hline $\mathrm{PAH}_{7}$ & 290.30 & 68.40 & 111.00 & 63.41 & 44.63 & 32.04 & 24.83 & 4.53 & n.d. & n.d. & 63.91 & \\
\hline $\mathrm{PAH}_{8}$ & 168.10 & 52.38 & 86.21 & 35.25 & 33.65 & 30.06 & 21.49 & n.d. & n.d. & n.d. & 42.71 & \\
\hline $\mathrm{PAH}_{9}$ & 103.00 & 44.06 & 120.90 & 42.07 & 33.39 & 4.76 & 16.46 & n.d. & n.d. & n.d. & 36.46 & \\
\hline $\mathrm{PAH}_{10}$ & 79.50 & 42.85 & 56.42 & 28.73 & 41.21 & 13.01 & 14.45 & n.d. & n.d. & n.d. & 27.62 & \\
\hline Total & 2649.70 & 984.19 & 1381.73 & 626.99 & 837.16 & 323.20 & 281.86 & 157.72 & 51.43 & 6.89 & & \\
\hline \multicolumn{13}{|c|}{ One-way ANOVA } \\
\hline $\mathrm{F}$ & 1.99 & & & & & & & & & & & \\
\hline
\end{tabular}

n.d.- not detected; naphthalene $\left(\mathrm{PAH}_{1}\right)$, acenaphtylene $\left(\mathrm{PAH}_{2}\right)$, acenaphthene $\left(\mathrm{PAH}_{3}\right)$, fluorine $\left(\mathrm{PAH}_{4}\right)$, anthracene $\left(\mathrm{PAH}_{5}\right)$, phenanthrene $\left(\mathrm{PAH}_{6}\right)$, fluoranthene $\left(\mathrm{PAH}_{7}\right)$, pyrene $\left(\mathrm{PAH}_{8}\right)$, benzo (b) anthracene $\left(\mathrm{PAH}_{9}\right)$ and chrysene $\left(\mathrm{PAH}_{10}\right)$.

$\mathrm{PAH}_{10}$ (79.50 ppm).

One-way ANOVA analysis for both heavy metals and PAHs shows there are significant differences between heavy metals and PAHs concentration and location ( $\mathrm{F}=$ 2.16 and $\mathrm{F}=1.99$ respectively). The concentration of heavy metals and PAHs are different for every location. SNK Test for both analysis (Tables 3 and $\mathbf{4}$ ) shows there are significant comparison between each heavy metals and PAHs. Hence, the selectivity of heavy metals is $\mathrm{Fe}>$ $\mathrm{Cr}>\mathrm{Ni}>\mathrm{Al}>\mathrm{Zn}>\mathrm{Pb}>\mathrm{Cu}>\mathrm{Co}$ while for PAHs is $\mathrm{PAH}_{1}>\mathrm{PAH}_{3}>\mathrm{PAH}_{2}>\mathrm{PAH}_{6}>\mathrm{PAH}_{5}>\mathrm{PAH}_{7}>\mathrm{PAH}_{4}$ $>\mathrm{PAH}_{8}>\mathrm{PAH}_{9}>\mathrm{PAH}_{10}$.

The emissions of heavy metals are mostly from the combustion of automobile engines. According to Garty et al. [11], $\mathrm{Pb}$ is the main heavy metal which originates from tetraethyl lead in engine fuel. This compound was an additive prior to the usage of unleaded fuel nowadays. Besides $\mathrm{Pb}$, almost all of the heavy metals pollutants were attributed to the vehicle transportation (i.e.: $\mathrm{Cu}$ from automobile engines' compartment, $\mathrm{Al}$ and $\mathrm{Fe}$ from the corrosion of vehicles' body). As for PAHs, the source of emissions is mainly from vehicles especially motorcycles $[12,13]$.

In this study, it was discovered that the concentration of $\mathrm{Fe}$ and naphthalene $\left(\mathrm{PAH}_{1}\right)$ were the highest in concentration for all of the sample locations. Naphthalene is the lightest molecular weight of PAHs so that it is the most abundant PAHs in atmosphere [14]. For heavy metals analysis, it was found that the concentration values at Locations 2, 5 and 8a were quite high. Whilst for PAHs analysis, Locations 1, 2, 3 and 4 were found to
Table 3. SNK test for heavy metals analysis.

\begin{tabular}{ccccc}
\hline Comparison & $\boldsymbol{q}_{\text {cal }}$ & $\boldsymbol{q}_{\text {tab }}(\mathbf{0 . 0 1})$ & $\mathbf{q}_{\text {tab }}(\mathbf{0 . 0 5})$ & P Value \\
\hline Fe-Co & 10.23 & 5.52 & 4.32 & 8 \\
Fe-Cu & 10.07 & 5.13 & 4.16 & 7 \\
Fe-Pb & 9.83 & 4.76 & 3.94 & 6 \\
Fe-Zn & 9.34 & 4.02 & 3.23 & 5 \\
Fe-Al & 6.51 & 3.44 & 2.98 & 4 \\
Cr-Co & 10.12 & 5.11 & 3.94 & 7 \\
Cr-Cu & 9.32 & 4.72 & 3.63 & 6 \\
Cr-Pb & 9.66 & 4.39 & 3.08 & 5 \\
Cr-Zn & 8.82 & 3.90 & 2.85 & 4 \\
Cr-Al & 5.49 & 2.77 & 1.55 & 3 \\
Ni-Co & 9.21 & 4.97 & 3.36 & 6 \\
Ni-Cu & 8.74 & 4.63 & 2.98 & 5 \\
Ni-Pb & 8.05 & 4.04 & 2.47 & 4 \\
Ni-Zn & 7.68 & 3.62 & 2.04 & 3 \\
Ni-Al & 4.08 & 2.39 & 1.34 & 2 \\
\hline
\end{tabular}

have higher concentration The higher concentrations may be due to high traffic near to these locations. The road along these locations is the main road from Bangi to Kajang. So, it is congested with many kinds of vehicle every day. Most of researchers reported that there is a positive relation between heavy metals/PAHs emissions and vehicles' traffic $[15,16]$. The rest of location gave an acceptable average concentration value in the range of 27.62 - $36.46 \mathrm{ppm}$. This is due to the low traffic flow along the road near these locations. Thus the concentra- 
Table 4. SNK Test for PAHs analysis.

\begin{tabular}{lcccc}
\hline Comparison & $\mathbf{q}_{\text {cal }}$ & $\mathbf{q}_{\text {tab }}(\mathbf{0 . 0 1})$ & $\mathbf{q}_{\text {tab }}(\mathbf{0 . 0 5 )}$ & P Value \\
\hline $\mathrm{PAH}_{1}-\mathrm{PAH}_{10}$ & 15.23 & 8.67 & 7.71 & 10 \\
$\mathrm{PAH}_{1}-\mathrm{PAH}_{9}$ & 14.76 & 8.34 & 7.58 & 9 \\
$\mathrm{PAH}_{1}-\mathrm{PAH}_{8}$ & 14.22 & 7.88 & 7.01 & 8 \\
$\mathrm{PAH}_{1}-\mathrm{PAH}_{4}$ & 13.89 & 7.42 & 6.69 & 7 \\
$\mathrm{PAH}_{1}-\mathrm{PAH}_{7}$ & 13.32 & 7.02 & 6.11 & 6 \\
$\mathrm{PAH}_{1}-\mathrm{PAH}_{5}$ & 12.71 & 6.79 & 5.97 & 5 \\
$\mathrm{PAH}_{1}-\mathrm{PAH}_{6}$ & 12.13 & 6.28 & 5.32 & 4 \\
$\mathrm{PAH}_{1}-\mathrm{PAH}_{2}$ & 11.64 & 5.66 & 5.77 & 3 \\
$\mathrm{PAH}_{1}-\mathrm{PAH}_{3}$ & 11.16 & 5.32 & 5.48 & 2 \\
$\mathrm{PAH}_{3}-\mathrm{PAH}_{10}$ & 12.83 & 6.45 & 4.36 & 9 \\
$\mathrm{PAH}_{3}-\mathrm{PAH}_{9}$ & 12.27 & 6.08 & 3.99 & 8 \\
$\mathrm{PAH}_{3}-\mathrm{PAH}_{8}$ & 11.65 & 5.65 & 3.25 & 7 \\
$\mathrm{PAH}_{3}-\mathrm{PAH}_{4}$ & 11.29 & 5.27 & 2.82 & 6 \\
$\mathrm{PAH}_{2}-\mathrm{PAH}_{4}$ & 10.73 & 4.87 & 2.24 & 5 \\
$\mathrm{PAH}_{2}-\mathrm{PAH}_{7}$ & 10.02 & 4.33 & 1.77 & 4 \\
$\mathrm{PAH}_{2}-\mathrm{PAH}_{5}$ & 9.69 & 3.78 & 1.32 & 3 \\
$\mathrm{PAH}_{2}-\mathrm{PAH}_{6}$ & 9.07 & 3.32 & 1.01 & 2 \\
\hline
\end{tabular}

tions of heavy metals and PAHs in lichens at the UKM campus clearly correspond to the exposure of the lichens, particularly Dirinaria picta, to source of vehicular emissions.

\section{Conclusion}

By this study, it is proven that Dirinaria picta acts as a good bioindicator in monitoring and determining the level of air quality. The main factor attributed is its ability to accumulate the air particles which contain heavy metals and PAHs. Both ICP-OES and GC/MS techniques were effective in determining heavy metals and PAHs respectively. In future, it is recommended to use transplanted lichen in order to see the trend of air pollutant in interested research area.

\section{Acknowledgements}

The authors appreciate the funding from Universiti Kebangsaan Malaysia, UKM-PTS-091-2010 in order to complete this study.

\section{REFERENCES}

[1] R. M. N. Hassan and N. A. Ibrahim, "Review of Air Pollution and Health Impact in Malaysia,” Environmental Research, Vol. 92, No. 2, 2003, pp. 71-77.

[2] Department of Environment, “Air Quality Monitoring," Malaysia, 2010.

http://www.doe.gov.my/en/content/air-quality-monitoring
[3] Department of Evironmental, “Air Pollution Index,” API, Malaysia, 2010.

http://www.doe.gov.my/portal/air-air-quality/air-pollutant -index-api/

[4] H. R. Negi, "Lichens: A Valuable Bioresource for Environmental Monitoring and Sustainable Development," Resonance, Vol. 8, No. 1, 2003, pp. 51-58. doi:10.1007/BF02834450

[5] M. E. Conti and G.Cecchetti, "Biological Monitoring: Lichens as Bioindicator of Air Pollution Assessment-A Review,” Environmental Pollution, Vol. 114, No. 3, 2001, pp. 471-492. doi:10.1016/S0269-7491(00)00224-4

[6] A. M. Mastral, J. M. López, M. S. Callén, T. García, R. Murillo and M. V. Navarro, "Spatial and Temporal PAH Concentrations in Zaragoza, Spain,” Science of Total Environment, Vol. 307, No. 1-3, 2003, pp. 111-124.

[7] IARC, "Polynuclear Aromatic Compounds, Part 1: Chemical, Environmental and Experimental Data," Vol. 32, IARC Monographs on the Evaluation of Carcinogenic Risks to Humans IARC Monographs, International Agency for Research of Cancer, Lyon, 1983.

[8] M. B. Mokhtar, L. B. Din, N. A. Lazim, R. I. Uzir, R. Idris and Y. Othman,” Determination of Trace Elements in Malaysian Lichens as Potential Indicators for Pollution by Using Inductive Couple Plasma Emission Spectrophotometry," Malaysia Journal of Analytical Sciences, Vol. 10, No. 1, 2006, pp. 185-188.

[9] M. Hoenig and A. M. de Kersabiec, "View-Sample Preparation Steps for Analysis by Atomic Spectroscopy Methods: Present Status,” Spectrochimica Acta Part B, Vol. 51, No. 11, 1986, pp. 1297-1307. doi:10.1016/0584-8547(96)01507-8

[10] S. Augusto, C. Máguas, J. Matos, M. J. Pereira and C. Branquinh, "Lichens as an Integrating Tool for Monitoring $\mathrm{PAH}$ Atmospheric Deposition: A Comparison with Soil, Air and Pine Needles," Environmental Pollution, Vol. 158, No. 2, 2010, pp. 483-489. doi:10.1016/j.envpol.2009.08.016

[11] J. Garty, M. Kauppi and A. Kauppi, “Accumulation of Air Elements from Vehicle in Transplanted Lichen in Urban Site,” Journal of Environmental Quality, Vol. 25, No. 2, 1996, pp. 265-272. doi:10.2134/jeq1996.00472425002500020009x

[12] L. R Bordajandi, M. Dabrio, F. Ulberth and H. Emons, "Optimization of the GC-MS Conditions for the Determination of the 16 EU Foodstuff Priority Polycyclic Aromatic Hydrocarbons,” Journal of Separation Science, Vol. 31, No. 10, 2008, pp. 1769-1778. doi:10.1002/jssc.200700562

[13] B. Maliszewska-Kordybach, "Sources, Concentrations, Fate and Effects of Polycyclic Aromatic Hydrocarbons (PAHs) in the Environment. Part A: PAHs in Air-A Review,” Polish Journal of Environmental Studies, Vol. 8, No. 3, 2006, pp. 131-136.

[14] R. Randall Bramston-Cook and R. Bilek, "Naphthalene in Ambient Air by GC/MS-MS Detection,” 2008 EPA/AWMA Symposium on Air Quality Measurement Methods and Technology, Chapel Hill, 4 November 2008. 
[15] C. G. Popescu, "Relation between Vehicle Traffic and Heavy Metals Content from the Particulate Matters," Romanian Reports in Physics, Vol. 63, No. 2, 2006, pp. 471-482.

[16] D. Castro, K. Slezakova, C. Delerue-Matos, M. C. Alvim-
Ferraz, S. Morais and M. C. Pereira, "Contribution of Traffic and Tobacco Smoke in the Distribution of Polycyclic Aromatic Hydrocarbons on Outdoor and Indoor $\mathrm{PM}_{2.5}$," Global NEST Journal, Vol. 12, No. 1, 2010, pp. 3-11. 